\section{JMLE \\ JOURNAL OF MEDIA LITERACY EDUCATION}

\title{
How a hands-on workshop offered by communication undergraduates in Israel enhanced fifth graders' news literacy skills
}

\section{$)$ open access}

Voices from the Field - Peerreviewed article

Citation: Gozansky, Y. (2021). How a hands-on workshop offered by communication undergraduates in Israel enhanced fifth graders' news literacy skills. Journal of Media Literacy Education, 13(1), 131-137. https://doi.org/10.23860/JMLE-2021$13-1-11$

\section{Corresponding Author:}

Yuval Gozansky

yuvalg@mail.sapir.ac.il

Copyright: () 2021 Author(s). This is an open access, peer-reviewed article published by Bepress and distributed under the terms of the Creative Commons Attribution License, which permits unrestricted use, distribution, and reproduction in any medium, provided the original author and source are credited. JMLE is the official journal of NAMLE.

Received: February 25, 2020

Accepted: October 11, 2020

Published: May 24, 2021

Data Availability Statement: All relevant data are within the paper and its Supporting Information files.

Competing Interests: The Author(s) declare(s) no conflict of interest.

\section{$\underline{\text { Editorial Board }}$}

\author{
Yuval Gozansky \\ Sapir Academic College, Israel
}

\begin{abstract}
This article describes a project-based academic course, called "Children's News: Theory and Social Involvement", in which communications undergraduate students worked with fifth graders in Israel to create their own newspapers. This hands-on workshop, developed at Sapir College in the south of Israel, helped children become literate in journalism and Newsmaking. They gained knowledge, writing skills, and self-esteem, as well as a sense of the social impact of journalism. The college students increased their own media literacy, gained pedagogy skills and news editing abilities, and got a glimpse of the point of view of children in a conflict area.
\end{abstract}

Keywords: communication undergraduates, Israel, journalism literacy, Kids' news, project-based learning.

\section{Journal of Media Literacy Education}

THE OFFICIAL PUBLICATION OF THE

National Association for Media Literacy Education (NAMLE)

Online at www.jmle.org 


\section{INTRODUCTION}

Israeli children are considered more involved in the consumption of news than most children around the world (Lemish, 1998; Lemish \& Pick-Alony, 2014). This is mainly because they are constantly aware of the complex political and security conflicts in their country, or as Alon-Tirosh put it, since they live in "a newsconsuming country" (2017, p. 135). In the last decade, however, a fierce campaign on the part of populist politicians, globally and locally, has set out to undermine the legitimacy of mainstream media, especially serious journalism (Peters, 2017).

Furthermore, public education in Israel does not include a compulsory news or media literacy program, even though "news and news consumption have a central role in Israel and are influencing the perceptions of children growing up there and their attitudes and expectations" (Alon-Tirosh \& Lemish, 2014, p. 109). The importance of journalism is rarely dealt with in elementary schools. Only some schools teach media (mostly in middle- and upper-class neighborhoods), and so most Israeli students, and particularly in the lower socio-economic periphery of Israel, are left to understand and interpret news and journalism without educational aid.

According to Article 17 of the UN Convention on the Rights of the Child, "States Parties recognize the important function performed by the mass media and shall ensure that the child has access to information" (United Nations, 1989). Considering this Article in combination with Article 28, which recognizes the right of the child to education, it is evident that in the UN's eyes children have a right not only to access media but to obtain the tools to fully understand it. In other words, children have a right to receive media literacy education.

In light of the above, and in the face of Israel's complex situation, the workshop described in this paper sought new ways to teach school children about journalism and news, empower them to be critical readers and creators, and improve their writing skills. Run by undergraduate communications students, the workshop is beginning its fourth year. It gained recognition and was part of the Israeli Council for Higher Education Community Involvement Course.

\section{Getting started: Developing the workshop}

As a former head of the Broadcast Journalism track in the Communications Department at Sapir Academic College, and as a researcher of children's media, I am interested in children's news. In 2015, I developed an academic course and practical workshop for B.A. communications students titled "News for Children". The course combined academic research with projectbased learning (Blumenfeld et al., 1991), in which my students learnt about children's news, analyzed existing news stories and then had to create news for elementary school aged children.

Initially, the course asked several theoretical questions:

- What exactly is news for children? In what way is it different from regular news?

- Should children's news be different from news for adults, and what does that say about the way adults think about children?

- Who is the target audience of children's news? What do they need and look for, and how do they interpret news?

- What is "right" and "wrong" in news for children?

Following our discussions, my students were asked to write, audio record or make a video news story for elementary school children. To assuage my students' anxieties (most of them never worked with children before), the assignment was specific. They were to create a "character report," a story of one child doing something newsworthy and interesting to a child audience. The subjects of the reports ranged from a girl working hard to earn enough money to buy her own tablet to a boy overcoming ADD by practicing longdistance running.

Following these first reports, the questions above ceased to be theoretical and became practical for my students, as they had to find their own answers. To enhance the deliberation, I invited an editor from a children's news program to share her everyday dilemmas and worldview. My students were surprised to learn that they shared the same difficulties as an experienced professional. The second assignment for my students to do was to create themed reports about issues of interest to children, with a minimum of three children interviewed for each. After journalistic research with children they had to find by themselves, my students were encouraged to report about problems facing children in the south of Israel and tell those stories from the children's point of view.

These assignments generated 15-20 news reports for children. I found that very limiting to my students, that they only heard feedback from me and other students, not from children yet. I came up with 2 solutions. First, I contacted a national website (Kids' News) and offered 
them the articles. The editors were happy to publish a number of them. ${ }^{1}$ Second, I had my students visit a nearby elementary school and discuss their news reports with fifth graders. The meeting was very productive. My students read their character reports aloud and school children were asked for their opinions. The comments ran from general statements ("it was very interesting," "I learnt something I didn't know") through critical ones ("I didn't understand that sentence," "it was too long") to personal beliefs ("I think this boy is very brave," "I think girls should be equal to boys in every sport"). Children were approached as critics and their views were valued by adults, which was empowering. My communications students saw firsthand how children react to news created for them and understood how important it is to think of different children when writing.

Following the visit, the school's headmaster asked me to bring my students back to work with hers. Seeing the educational potential for both my students and for school children in the south of Israel, I choose to take that challenge, and so we did the following year (2016).

\section{THE JOURNALISM LITERACY WORKSHOP IN TWO STEPS}

\section{Step One: Students' preparation}

In building the journalism workshop, I created a set of assumptions, goals, and guidelines. My assumptions were:

- Children must create news reports themselves

- They must be free to express their thoughts, beliefs, and criticisms

- Students working with the children should be knowledgeable in children's news dilemmas

- The work should be done in small groups (ideally four children per student) with no school authorities present during meetings

- The reports the children create must be publicly available once they are finished

Based on those ideas, the workshop was framed as a combination of an academic course for the communications students and a news workshop for fifth graders. The course was titled “Children's News:

\footnotetext{
${ }^{1}$ For example, one story published in text and video was about girls playing soccer (in Hebrew): https://bit.ly/3qR5D4P

2 A sample of undergraduate students reports published on Kids' News website (in Hebrew):

https://news.galim.org.il/pages/22309
}

Theory and Social Involvement". The academic curriculum was built of two consecutive semesters, with the first semester similar to the academic and practical workshop for students described above. The students created news stories about children and children's issues, which were made public on Kids' News. ${ }^{2}$

The students also each prepared a ten-minute presentation, teaching one specific lesson, for the children's journalism literacy workshop. Among the subjects the students choose were

- the Five Ws (who, what, when, where and why),

- newsworthiness (new-important-interesting),

- journalistic research,

- journalism photography,

- headlines and article structures,

- freedom of speech, and

- the difference between facts and opinions.

\section{Step Two: Students working with children}

The second semester was dedicated to the journalism literacy workshop, where the undergraduate students were divided between two schools. The first was a middle-class public school on a Jewish Kibbutz, and the second was a Jewish religious school in a neighboring small town, with pupils from a lower socio-economic class (as determined by the location of the school, not the individual pupils). Those two schools were very different, but growing up in the south of Israel, near the Gaza Strip, all children were accustomed to missile attacks, siren alarms and fighter aircraft flying regularly over their heads. Thus, their concepts of news were characterized by their preoccupation with terror and the existential threat they were experiencing, and found news reports realistic.

We chose to work with fifth graders due to their writing and expressive abilities. The "News for Kids" workshop was free for interested children, and took place during school hours. The workshop consisted of 13 meetings of one hour and 20 minutes each. Each meeting started with a ten-minute student presentation, dealing with one of the above journalistic subjects (which changed slightly each year). The presentations engaged the children with Q\&A and small games. Following, each student was assigned to four to five

https://news.galim.org.il/pages/22310 https://news.galim.org.il/pages/22311 https://news.galim.org.il/pages/22313 https://news.galim.org.il/pages/22312 
children to work on further assignments, which enabled the students to give individual guidance.

The first assignment for the children was to write a news report about someone they knew personally (a family member, neighbor, schoolmate, etc.). The idea was to decrease the natural fear of approaching someone and asking them questions. Before the reporting phase, they were each asked to prepare a journalistic research paper. The students helped the children write at least ten research questions, to which they would get answers by the next meeting. During the question preparation, the students and I practiced the Five Ws with the children, discussed what was newsworthy in the stories they choose (every story was newsworthy), and directed them in finding answers through the news gathering process.

The subjects they chose ranged from their parents' and grandparents' stories, through friends and teachers at school, to the town's hairdresser or the Kibbutz's museum curator. Most children were happy to ask questions and get serious answers from adults. The interviews turned out to be a great opportunity for personal connection, as, for example, the children found out more about their family's or town's history. Some children didn't interview anybody and came to the next meeting empty-handed. I encouraged my students to talk in private with those children and ask how they could help them. One child told me that he had nothing to write about, so I asked him what his hobbies were. He said he loved watching gamers on YouTube, so I suggested he write an article about them. After a few weeks he wrote an opinion piece about the hypocrisy of his parents criticizing him watching YouTube gamers while his father watched sports on television. ${ }^{3}$

The next step was asking the children to write news stories based on their research. Some were fluent writers; others had their parents help them. The children wrote either on classroom computers or personal laptops, allowing the college students to go from one child to the other as they wrote the story together. Because the students were young adults in their twenties, they were not looked upon as teachers but as guides. They did not give critical feedback or grades, which made their comments and connection more personal. They became in a way like older siblings,

\footnotetext{
${ }^{3}$ Link to this story on our workshop's dedicated web-journal (in Hebrew): https://bit.ly/2ZJn9fC

${ }^{4}$ Link to this story on our workshop's dedicated web-journal (in Hebrew): https://bit.ly/3qM5y2g

5 Homepages of the second workshop's web-journals (in Hebrew):
}

sharing interests such as favorite sports clubs. The students got a glimpse of childhood in a different time and place: ten to twelve years younger than themselves, on the southern periphery of Israel.

All articles were then sent to me, as the editor of the children's newspaper. I read them, corrected phrasing, added headlines and chose photos from the ones children sent. Every story was publishable, as long as it was true. Sometimes I asked my students to go back to a child and ask for more information or request answers for critical questions. For example, one boy wrote a story about his grandfather, who was a soccer player in his youth. ${ }^{4}$ According to the information the boy got, his grandfather played in the National Cup final. But simple online fact-checking showed that his team never played in a Cup final. I asked the boy to go back and check with his sources. The next week he corrected the article: his grandfather had played in the National Cup final for youth. A simple mistake and a vital correction.

Finished articles were sent to our webmaster, a student who was responsible for our dedicated webjournal. Each school had its own website, with photos of the children writing. ${ }^{5}$ Links to the articles were immediately sent to students, children, and headmasters through social media, to be shared with family, friends, and peers. The immediate online publication served several purposes: creating a feeling of success on the part of the young journalists, enabling immediate feedback, and most importantly, motivating other children in the workshop.

Some children moved easily to the next report, where they were free to choose the subject. Others struggled with the first one until the end of the workshop. The stories children wrote about were diverse - their parents' professions, family history, social projects they took part in, places they loved - but also issues specific to children - a girl facing cyber bullying, fears related to growing up in a conflict zone.

We had two extraordinary workshop meetings. One was a field visit to the most popular television news studio, Channel 12, near Jerusalem. Visiting TV news studios and meeting well-known journalists (especially the hosts of Young Newscast, a well-known children's news program) was informative for both children and college students. ${ }^{6}$ The second was the workshop's

https://hanegev2018.wixsite.com/newsforkidsharoe; https://hanegev2018.wixsite.com/newsforkidshanegev

${ }^{6}$ A story written after the educational visit on our workshop's web-journal (in Hebrew): https://bit.ly/2NyfCO3 
festive last meeting, in which participants summarized their experiences. Before this last meeting we printed a joint hardcopy newspaper, Young Journalists, containing all the articles created by participants from

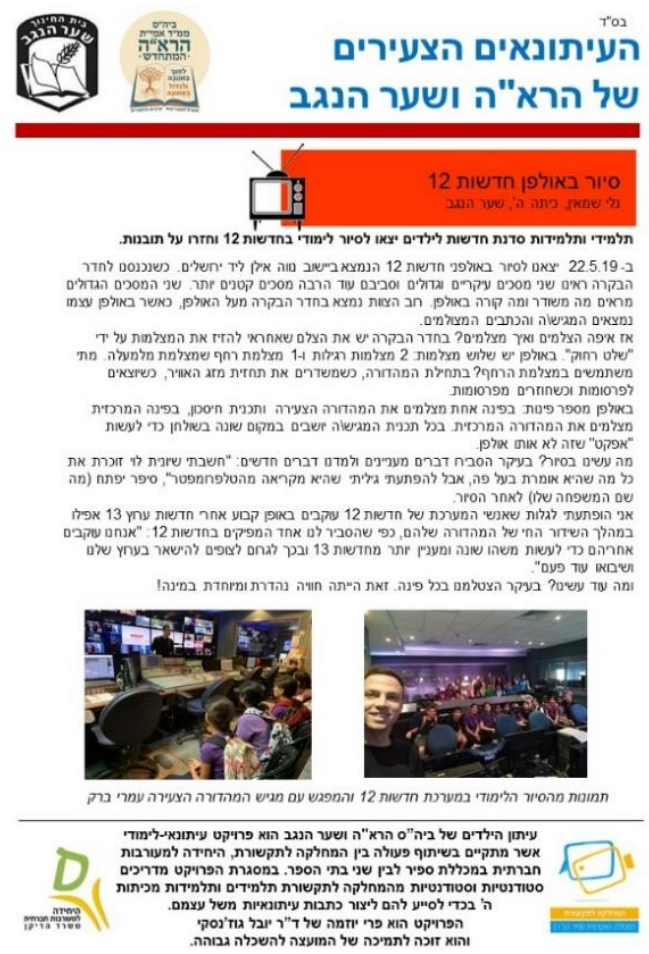

both schools. The newspaper was 20 pages, with 34 original articles by children (see Figure 1)!

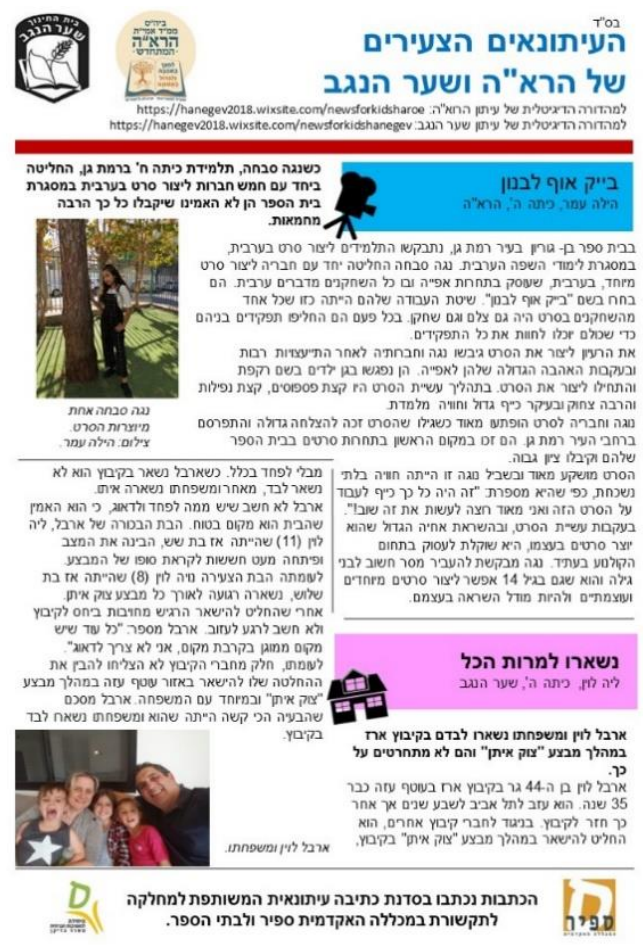

Figure 1. The first and last pages of the workshop's 2019 Hardcopy Newspaper

\section{SUMMARY AND CONCLUSIONS}

\section{Obstacles, solutions and gains in journalism literacy}

Reviewing 3 years of "Children's News: Theory and Social Involvement" reveals that both children and older students grew personally and developed their news literacy skills (Hobbs, 2010; Moore, 2013; Maksl et al., 2015). In only 13 meetings, every child in the workshop wrote at least one published news report, and some wrote more. All children became creators, Anderson et al.'s (2001) highest level of learning. They came to understand first-hand what it takes to write a news story. They could feel the challenges facing reporters but also the thrill of seeing their work published and read by others. For some of them, appreciation came only from their parents; others received responses from teachers and peers (see Table 1).

Despite difficulties, the children showed the following gains in news and journalism literacy:

- Understanding journalists' work and how it is done
- Seeing events through journalistic eyes, in text and visually

- Competently engaging with news and journalism

- Realizing that what happens to children can be newsworthy

- Understanding different points of view

- Being critical

- Seeing journalism as an important part of citizenship and democracy, and

- Considering journalism as a possible profession

The college communications students also gained from this workshop. First, in terms of media literacy, as they had to prepare and figure out how to teach journalism. In addition, this project-based learning forced students to see the complex connection between news literacy and practical journalism work, as they become editors for the children's reports and articles (Brooks \& Ward, 2007).

And, maybe most importantly, they met children from a different generation and saw the world through their eyes and words. 
Table 1. Obstacles, solutions, and what children gained during the process

\begin{tabular}{|c|c|c|}
\hline Obstacles & Solutions & Gains \\
\hline Lack of journalistic skills & $\begin{array}{l}\text { Basic essentials of journalism } \\
\text { taught (in headlines) }\end{array}$ & Increased knowledge \\
\hline $\begin{array}{l}\text { Fear of approaching } \\
\text { interviewees }\end{array}$ & $\begin{array}{l}\text { First story about people they } \\
\text { already know }\end{array}$ & $\begin{array}{l}\text { Comfort with approaching } \\
\text { interview subjects, an ability to } \\
\text { see with "journalistic eyes" }\end{array}$ \\
\hline $\begin{array}{l}\text { Late and non-responsive } \\
\text { children }\end{array}$ & $\begin{array}{l}\text { Encouraging them personally, } \\
\text { slowly, and non-judgmentally }\end{array}$ & $\begin{array}{l}\text { Realization that everyone can be } \\
\text { a journalist }\end{array}$ \\
\hline $\begin{array}{l}\text { Difficulties in writing and } \\
\text { building a news report }\end{array}$ & $\begin{array}{l}\text { Students help each pupil, one-on- } \\
\text { one }\end{array}$ & $\begin{array}{l}\text { Improved writing skills, } \\
\text { understanding of report parts: } \\
\text { headlines, journalistic body, } \\
\text { photo editing }\end{array}$ \\
\hline Low motivation to write & $\begin{array}{l}\text { Fast publication of the articles } \\
\text { online and spreading links } \\
\text { through social media }\end{array}$ & $\begin{array}{l}\text { Feeling the social impact of } \\
\text { journalism, greater self-esteem }\end{array}$ \\
\hline
\end{tabular}

Working on news stories with children living in the south of Israel today meant helping them to write about their favorite YouTubers and vacations but also about the death of a grandparent, the difficulties of immigration to Israel, and life in fear of missile attacks and insecurity. For my students (and me), it was rich experience, one of overcoming prejudice about the abilities of children, their intelligence and curiosity. Based on this practice, educators and in particular those who work in difficult socio-political conditions, could look at neighboring schools and initiate a partnership between college students and school children, for the benefit of developing news literacy and the promotion of change through education.

\section{ACKNOWLEDGEMENTS}

The author would like to thank the Israeli Council for Higher Education for its support of the project.

\section{REFERENCES}

Alon-Tirosh, M. (2017). Children and news: Opinions of children's news program creators in Israel. Journal of Children and Media, 11(2), 132-146. https://doi.org/10.1080/17482798.2017.1302489

Alon-Tirosh, M., \& Lemish, D. (2014). "If I was making news": What do children want from news? Participations: Journal of Audience \& Reception Studies, 11, 108-129.

Anderson, L.W. (Ed.), Krathwohl, D.R. (Ed.), Airasian, P.W., Cruikshank, K.A., Mayer, R.E., Pintrich, P.R., Raths, J., \& Wittrock, M.C. (2001). A taxonomy for learning, teaching, and assessing: A revision of Bloom's Taxonomy of Educational Objectives. Longman.

Blumenfeld, P. C., Soloway, E., Marx, R. W., Krajcik, J. S., Guzdial, M., \& Palincsar, A. (1991). Motivating project-based learning: Sustaining the doing, supporting the learning. Educational Psychologist, 26 (3-4), 369-398. https://doi.org/10.1080/00461520.1991.9653139

Brooks, D. E., \& Ward, C. J. (2007). Assessing students' engagement with pedagogies of diversity. Journalism \& Mass Communication Educator, 62, 243-262. https://doi.org/10.1177/107769580706200303

Hobbs, R. (2010, August). News literacy: What works and what doesn't. Paper presentation at the Association for Education in Journalism and Mass Communication conference, Denver, CO.

Lemish, D. (1998). What is news? A cross cultural examination of kindergartners' understanding of news. Communications: European Journal of Communication Research, 23, 491-504. https://doi.org/10.1515/comm.1998.23.4.491

Lemish, D., \& Pick-Alony, R. (2014). Inhabiting two worlds: The role of news in the lives of Jewish and Arab children and youth in Israel. International Communication Gazette, 76, 128-151. https://doi.org/10.1177/1748048513504165

Maksl, A., Ashley, S., \& Craft, S. (2015). Measuring news media literacy. Journal of Media Literacy Education, 6(3), 29-45. https://digitalcommons.uri.edu/jmle/vol6/iss $3 / 3$ 
Moore, D. C. (2013). Bringing the world to school: Integrating news and media literacy in elementary classrooms. Journal of Media Literacy Education, 5(1), 326-336.

https://digitalcommons.uri.edu/jmle/vol5/iss1/5

Peters, M. (2017). Education in a post-truth world. Educational Philosophy and Theory, 49(6), 563-566. https://doi.org/10.1080/00131857.2016.1264114

United Nations (1989). Convention on the Rights of the Child.

https://treaties.un.org/doc/Treaties/1990/09/199009 02\%2003-14\%20AM/Ch_IV_11p.pdf 